\title{
GENETIC AND PHENOTYPIC PARAMETERS OF SOME LIFETIME AND LONGEVITY TRAITS IN HOLSTEIN COWS OF COMMERCIAL FARM IN EGYPT
}

\section{S. Abou-Bakr}

Department of Animal Production, Faculty of Agriculture, Cairo University, Giza, Egypt

\section{SUMMARY}

Data used in this study comprised 2730 lactation records for 850 Holstein cows sired by 316 sires. Holstein cows belonging to a commercial farm. The objectives were to estimate the heritability and genetic and phenotypic correlations of some lifetime and longevity traits of Holstein cows. Traits studied were total lifetime milk (TLM), productive life or longevity (Plife), age at disposal or lifetime (Cull age), average calving interval (CIAV), and longevity index (LI, \%).

The mean of TLM, Plife, Cull age, CIAV and LI were $26935 \mathrm{Kg}, 47.5 \mathrm{month}, 74.8$ month, 508.5 day and 51.5\%, respectively. The heritability estimates for these traits were $0.24,0.18,0.18,0.12$ and 0.17 , respectively. The genetic and phenotypic correlations between TLM and Plife and Cull age and LI traits were positive and greater than 0.75. The genetic correlations between CIAV and other traits were negative.

Keywords: Genetic parameters, lifetime, longevity, Holstein and Egypt

\section{INTRODUCTION}

Longevity is the second most important trait after milk production used in selection indices all over the world. It is an easy trait to record. One common way to measure longevity is length of productive life, the time from first calving to culling or death of a cow. Increased longevity reduces the direct costs of raising or purchasing replacement females (Forabosco et al., 2004).

Longevity is a large contributor to the profitability of a dairy farm. However, longevity is a complex trait and is a function of a large number of factors, namely the milk yield potential, the fertility and health of the animal as well as the physical and management characteristics of the cow (Berry et al., 2005). Longevity is a measure of the success of the cow to survive both voluntary and involuntary culling (Vollema and Groen, 1996). Longevity is of major economic importance in dairy cattle (VanRaden and Wiggans, 1995).

The ability to both produce and reproduce for many years is a desirable characteristic in dairy cattle, since it takes from one to three years of production for a dairy cow to repay her cost of rearing. Beyond that period, milk revenue over direct costs becomes gross profit. A long productive life is financially beneficial and also allows selection of more offspring of the better producing animal (Hogue and Hodges, 1980).

Genetic improvement in dairy cows have led to animals that produce significantly greater yields in a lifetime, therefore there is increase in the total lifetime number of

Issued by The Egyptian Society of Animal Production 
days in milk. Genetic selection for high production has been accompanied by a reduction in fertility (Dematawewa and Berger, 1998 and Royal et al., 2000). In the USA few Holstein cows survive beyond their fifth parity, as a result their average lifetime number of parities has decreased over the past 20 years from 3.4 to 2.8 (Tsuruta et al., 2005).

The objectives of this study were to estimate the heritability, genetic and phenotypic correlations of some lifetime and longevity traits of Holstein cows in a commercial farm in Egypt.

\section{MATERIALS AND METHODS}

Data included 2730 lactation records for 850 Holstein cows sired by 316 sires. Data were collected from a commercial farm (International Company for Animal Wealth), located at Giza Governorate in Egypt. The records were taken during the period from 1989 to 2004.

Most of the cows were imported as pregnant heifers from USA. Cows were artificially inseminated at the third estrus observed after parturition using frozen semen imported from USA and Canada. All cows were machine milked according to their productivity.

Months of birth were grouped into four seasons, winter (December- February), Spring (March - May), summer (June- August) and autumn (September - November). Year of birth was classified into four groups $(1=1989-1992,2=1993-1996,3=$ 1997 - 2000, and 4=2001 - 2004).

Definitions and notations of some lifetime and longevity traits are given below:

1 -Total lifetime milk (TLM, Kg) = including production to the end of each lactation,

2 - Productive life or longevity (Plife, months) = the period from first calving to disposal from farm,

3 - Age at disposal or lifetime (Cull age, months) $=$ the time between birth date and disposal date,

4 - Average calving interval (CIAV, months), and

5 - Longevity index $(\mathrm{LI}, \%)=$ calculated as the cow's lifetime days in milk divided by its longevity, expressed as a percentage. The LI can be considered as a measure of the cow's lifetime efficiency, that is, the proportion of her days spent producing milk.

Statistical analysis:

The data were analyzed using SAS (2004) to investigate any effect of year and season of birth and age at first calving on some lifetime and longevity traits of Holstein cows. The following statistical model was used:

Where,

$$
\mathrm{Y}_{\mathrm{ijkl}}=\mu+\mathrm{YB}_{\mathrm{i}}+\mathrm{SB}_{\mathrm{j}}+\mathrm{bx}_{\mathrm{ijk}}+\mathrm{e}_{\mathrm{ijkl}} \text {, }
$$

$\mathrm{Y}_{\mathrm{ijk} \mathrm{l}}=$ lifetime and longevity traits,

$\mu=$ the overall mean,

$\mathrm{YB}_{\mathrm{i}}=$ the fixed effect of the $\mathrm{i}^{\text {th }}$ year of birth $(\mathrm{i}=1,2,3,4)$,

$\mathrm{SB}_{\mathrm{j}}=$ the fixed effect of the $\mathrm{j}^{\text {th }}$ season of birth $(\mathrm{j}=1,2,3,4)$,

$\mathrm{b}=$ the regression coefficient of lifetime and longevity traits on age at

first calving, 
$\mathrm{X}_{\mathrm{ijk}}=$ the deviation of the age at first calving from its mean, as a co-variable, and $\mathrm{e}_{\mathrm{ijkl}}=$ random error term.

Estimates of heritability of lifetime and longevity traits were estimated using VCE 6.0.2 software (Groeneveld et al., 2008). The following statistical model was used:

Where,

$$
\mathrm{Y}_{\mathrm{ijklm}}=\mu+\mathrm{YB}_{\mathrm{i}}+\mathrm{SB}_{\mathrm{j}}+\mathrm{bx}_{\mathrm{ijk}}+\mathrm{A}_{\mathrm{l}}+\mathrm{e}_{\mathrm{ijklm}},
$$

$\mathrm{A}_{1}=$ Animal's random additive genetic effect. The rest of the model (B) was the same as in the model (A).

Also, phenotypic and genetic correlations were estimated by VCE 6.0.2 software (Groeneveld et al., 2008).

\section{RESULTS AND DISCUSSION}

Coefficient of determination $\left(\mathrm{R}^{2}\right)$, and level of significance $(\mathrm{P}<)$ of factors affecting lifetime and longevity traits are shown in Table 1. This Table shows the coefficient of determination $\left(\mathrm{R}^{2}\right)$ for the full model, which is a measure of the proportion of total variability accounted for by the effects in the model. The value of $\mathrm{R}^{2}$ ranged from 0.03 for CIAV to 0.25 for LI trait. These estimates of $\mathrm{R}^{2}$ indicated the relatively small importance of these effects include in the statistical model, in determining the total variability of all studied traits except LI trait.

Significance of each effect was judged from the F-ratio $(\mathrm{P}<$, Table 1$)$. The effect of year of birth was highly significant for all traits, which is in agreement with Alhammad (2008). The effect of season of birth was not significant for all traits except CIAV $(\mathrm{P}<0.0002)$. Also, the effect of age at first calving as a co-variable was highly significant except for Cull age and CIAV traits.

Table 1. Coefficient of determination $\left(R^{2}\right)$, and level of significance $(P<)$ of factors affecting lifetime and longevity traits of Holstein cows

\begin{tabular}{lcccccc}
\hline Source of variation & $\mathrm{df}$ & \multicolumn{5}{c}{$\mathrm{P}<$} \\
\cline { 2 - 7 } & & TLM & Plife & Cull age & CIAV & LI \\
\hline Year of birth & 3 & $<0.0001$ & $<0.0001$ & $<0.0001$ & $<0.0428$ & $<0.0001$ \\
Season of birth & 3 & 0.5293 & 0.7175 & 0.6834 & $<0.0002$ & 0.4761 \\
Age at first calving & 1 & 0.0058 & 0.0019 & 0.2685 & 0.6475 & $<0.0001$ \\
$\mathbf{R}^{2}$ & & 0.15 & 0.17 & 0.16 & 0.03 & 0.25 \\
\hline
\end{tabular}

Table 2 shows arithmetic means (X), standard deviations (SD) and coefficients of variation $(\mathrm{CV} \%)$ of lifetime and longevity traits of Holstein cows. The mean of TLM in this study was $26935 \mathrm{Kg}$. This estimate was higher than that found by Honnette et al., (1980a \& 1980b), Hoque and Hodges (1980), Jairath et al. (1994) and Atil and Khattab (1999) but lower than reported by Alhammad (2008).

The average of productive life trait (Plife) was 47.5 months. This value falls within the range (27.3 to $78.7 \mathrm{month}$ ) reported in the literature (Hargrove et al.; 1969, Honnette et al. 1980a \&1980b; Hoque and Hodges ,1980; Jairath et al., 1994 ; Atil and Khattab ,1999); Hare et al. ,2006; Ajili et al., 2007 and Alhammad , 2008). The mean number of lactations completed (NLC) was 3.2. This estimate was higher than estimates in some studies (2.56 lactation, Jairath et al.,1994 and 2.6 lactation, Ajili et al., 2007) and almost the same to Hoque and Hodges, 1980 (3.3 lactation). In other 
studies the means of NLC were higher than estimated in this study (5.26 lactation, Atil and Khattab, 1999 and 5.5 lactation, Alhammad, 2008).

Table 2. Arithmetic means (X), standard deviations (SD) and coefficients of variation (CV\%) of lifetime and longevity traits of Holstein cows

\begin{tabular}{lccc}
\hline Trait & X & SD & CV\% \\
\hline TLM, Kg & 26935 & 10970 & 41.0 \\
Plife, month & 47.5 & 18 & 37.5 \\
Cull age, month & 74.8 & 18 & 23.8 \\
CIAV, days & 508.5 & 121.7 & 23.9 \\
LI, \% & 51.5 & 7.1 & 13.8 \\
\hline
\end{tabular}

Mean of Cull age (lifetime) was 74.8 month as shown in Table (2) and comparable to Hoque and Hodges, 1980 (72 month). Alhammad (2008) found that mean of lifetime trait was 105.3 month. The difference between Cull age and Plife trait is the age at first calving (26.7 month), which remains relatively constant.

The average of calving interval was 508.5 day. The present mean of CIAV is higher than that reported by Nigm et al. (429 day; 2006), Ajili et al. (427 day; 2007) and Alhammad (439 day; 2008). The calving interval is traditionally considered the main fertility indicator during the productive life of dairy cattle (INTERBUUL, 2007). The CI is easily recordable as the time between two subsequent calving and is less affected by data quality issues than other fertility traits (Pryce et al., 2000). This results in a number of unfavorable features for CI (e.g. CI is available only for the most fertile cows that calve two or more times; it is not an early measure of fertility; and it is not an adequate selection tool for breeding organizations as a selection tool).

Mean of longevity index (LI \%) was 51.5. The index expresses the efficiency of an individual cow in terms of the proportion of its total life it spent producing milk (Haworth et al., 2008).

Coefficients of variation of some lifetime and longevity traits as shown in Table 2 were ranged from $41 \%$ of TLM to $13.8 \%$ of LI.

The differences between our results and those reported by other researchers could be due to differences in climatic and management conditions, number of records used in the study and affecting factors considered in the statistical model.

Estimates of heritability and their standard errors of some lifetime and longevity traits of Holstein cows are presented in Table (3). The estimate of $h^{2}$ of TLM is 0.24, which is in accordance with the estimate of Gill and Allaire $(0.25 ; 1975)$, Atil and Khattab $(0.24 ; 1999)$, Daliri et al. $(0.25 ; 2008)$. The estimate of $h^{2}$ was higher than the range of estimates in other studies (0.11; Hoque and Hodges (1980) to 0.13; Jairath et al., 1994).

The estimates of heritability of productive life (Plife) and lifetime (Cull age) were similar (0.18). These estimates were higher than estimates in the literature (Hargrove et al., 1969; Hoque and Hodges, 1980; Jairath et al., 1994; Alhammad, 2008 and Daliri et al., 2008).

A heritability estimate of 0.12 was obtained for CIAV (Table 3). Dong and Van Vleck (1989) reported heritability for calving interval of 0.15 . Several estimates reported were lower than 0.1 (Campos et al., 1994; Pryce et al., 2000; Ojango and Pollott, 2001 and Dal Zotto et al., 2007). The heritability estimate of LI \% was 0.17 (Table 3). No previous estimates for this trait were found in the literature. 
Table 3. Estimates of heritability $\left(h^{2}\right)$ and their standard errors (SE) of some lifetime and longevity traits of Holstein cows

\begin{tabular}{lcc}
\hline Trait & $\mathbf{h}^{2}$ & SE \\
\hline TLM, Kg & 0.24 & 0.08 \\
Plife, month & 0.18 & 0.08 \\
Cull age, month & 0.18 & 0.08 \\
CIAV, days & 0.12 & 0.07 \\
LI, \% & 0.17 & 0.07 \\
\hline
\end{tabular}

Vollema and Groen (1996) suggested that when longevity traits were used in a breeding program, heritability estimates should be from a population that resembles the population in the breeding program. Also, other recommendations are to use the most recent data possible and to reestimate heritabilities over time. If population dynamics change, estimation of heritabilities that will hold for future generations is impossible, especially for longevity traits, which are measured later than milk production and conformation traits.

Genetic and phenotypic correlations between some lifetime and longevity traits are shown in Table (4). The genetic and phenotypic correlations between TLM and each of Cull age and LI traits are positive and greater than 0.753. The genetic correlations between CIAV and other traits were negative. But the phenotypic correlation among CIAV and TLM was small and negative, indicating that a substantial antagonism between high yield and fertility exists.

The genetic correlations were higher than the phenotypic correlations, being similar to literature results (Short and Lawlor, 1992; Chauhan et al., 1993; Vollema and Groen, 1996; Atil and Khattab, 1999 and Alhammad, 2008). Both genetic and phenotypic correlations between TLM and longevity traits, namely, productive life, culling age and longevity index were $>0.826$. High genetic correlations between TLM and Plife and cull age traits ( 0.899 and 0.902 , respectively) indicate that older cows were also genetically the high producers.

The genetic and phenotypic correlations between Plife and Cull age were almost one (0.999), being similar to Hoque and Hodges (1980). They reported that high genetic correlations between lifetime and longevity traits suggest that they essentially measure the same trait and one of these measures, total lifetime milk, will measure lifetime performance and longevity.

Table 4. Genetic (above diagonal) and phenotypic (below diagonal) correlations among lifetime and longevity traits of Holstein cows

\begin{tabular}{lccccc}
\hline Traits & TLM & Plife & Cull age & CIAV & LI \\
\hline TLM & & 0.899 & 0.902 & -0.687 & 0.882 \\
Plife & 0.887 & & 0.999 & -0.711 & 0.761 \\
Cull age & 0.886 & 0.999 & & -0.711 & 0.760 \\
CIAV & -0.010 & 0.063 & 0.063 & & -0.571 \\
LI & 0.826 & 0.754 & 0.753 & 0.092 & \\
\hline
\end{tabular}




\section{CONCLUSIONS}

The interest in implementing longevity trait in the breeding goal for the Holstein population in Egypt is mainly due to the need of dairy farmers to have cows with higher economic efficiency. Interpretation of lifetime production and longevity in more detail is difficult because the reasons for disposal are not recorded routinely.

\section{REFERENCES}

Alhammad,H.O., 2008. A genetic study of lifetime performance in Holstein Friesian cattle in Egypt. Ph.D. Thesis Fac. Of Agric., Cairo University, Egypt.

Ajili, N., B. Rekik ; A. Ben Gara, and R. bouraoui, 2007. Relationships among milk production, reproductive traits, and herd life for Tunisian Holstein-Friesian cows. African J. of Agricultural Research Vol.2 (2):47-51.

Atil, H. and A.S. Khattab, 1999. Lifetime production and longevity of Holstein Friesian cows in relation to their sire transmitting ability. Pakistan J. Biological Sci., 2(1):69-73.

Berry, D.P.; B.L. Harris; A.M. Winkelman and W. MOntgomerie, 2005. Phenotypic associations between traits other than production and longevity in New Zealand dairy cattle with special emphasis on management traits. INTERBULL meeting, June 2-5 2005, Uppsala, Sweden.

Campos, M.S.; C.J. Wilcox; C.M. Becerril and A. Diz, 1994. Genetic parameters for yield and reproductive traits of Holstein and Jersey cattle in Floraida. J.Dairy Sci., 77: 867-873.

Chauhan, V.P.S.; J.F. Hayes and L. K. Jairath, 1993. Genetic parameters of lifetime performance traits in Holstein cows. J. Anim. Breed. Gent., 110:135.

Dal Zotto, R.; M.De Marchi ; C. Dalvit ; M. Cassandro ; L. Gallo ; P. Carnier and G. Bittante, 2007. Heritabilities and genetic correlations of body condition score and calving interval with yields, somatic cell score and linear type traits in Brown Swiss cattle. J. Dairy Sci., 90: 5737-5743.

Daliri, Z.; S.H. Hafezian; A.Shad Parvar and G. Rahimi, 2008. Genetic relationships among longevity, milk production and linear type traits in Iranian Holstein Cattle. J. Anim. And Vet. Advances, 7(4): 512-515.

Dong, M.C. and L.D. Van Vleck, 1989. Estimates of genetic and environmental (co) variances for first lactation milk yield, survival and calving interval. J. Dairy Sci., 72:678.

Dematawewa, C.M.B. and P.J. Berger, 1998. Genetic and phenotypic parameters for 305-day yield, fertility and survival in Holsteins. J.Dairy Sci., 81: 2700-2709.

Forabosco, F.; A.F. Groen ; R. Bozzi ; J. Van Arendonk ; F. Filippini ; P. Boettcher and P. Bijma, 2004. Phenotypic relationships between longevity, type traits and production in Chianina beef cattle. J. Anim. Sci., 82: 1572-1580.

Gill, G.S. and F.R. Allaire, 1975. Relationship of first lactation performance to lifetime production and economic efficiency. J. Dairy Sci., 59: 1319.

Groeneveld, E.; M. Kovac and N. Mielenz, 2008. VCE 6.0.2, Co-variance components estimation package, Institute of Farm Animal Genetics, Mariensee, Germany.

Hare, E.; H.D. Norman and J.R. Wright, 2006. Survival rates and productive herd life of dairy cattle in the United States. J. Dairy Sci., 89:3713-3720. 
Hargrove, G.L.; J.J. Salazar and J.E. legates, 1969. Relationships among first lactation and lifetime measurements in a dairy population. J. Dairy Sci., 52:651656.

Haworth, G.M.; W.P. Tranter; J.N. Chuck; Z. Cheng and D.C.Wathes, 2008. Relationships between age at first calving and first lactation milk yield, and lifetime productivity and longevity in dairy cows. The Veterinary Record,162: 643-647.

Hogue, M and J.Hodges, 1980. Genetic and phenotypic parameters of lifetime production traits in Holstein cows. J.Dairy Sci., 63: 1900-1910.

Honnette, J.E.; W.E. Vinson; J.M. White, and R.H. Kliewew, 1980a. Contributions of descriptively coded type traits to longevity of Holstein cows. J. Dairy Sci., 63:807-815.

Honnette, J.E.; W.E. Vinson; J.M. White, and R.H. Kliewew, 1980b. Prediction of herd life and lifetime production from first lactation production and individual type traits in Holstein cows. J. Dairy Sci., 63: 816-824.

INTERBULL, 2007. National Evaluation Systems Information. Httb://www.interbull.SLU.Se/national_gesinfo2/framesida-ges.htm.Accessed Auguest 2007.

Jairath, L.K.; J.F. Hayes and R.I. Cue, 1994. Multitrait restricted maximum likelihood estimates of genetic and phenotypic parameters of lifetime performance traits for Canadian Holsteins. J. Dairy Sci., 77:303-312.

Nigm, A.A.; S.Abou-Bakr; K. Abdel_Rahman; R.R. Sadek and M.A. Morsy, 2006. Dairy performance characteristics of Holstein friesian in a large commercial herd in Egypt. J. Agric. Mansoura Univ., 31(6):3407-3414.

Ojengo, J.M. and G.E. Pollott, 2001. Genetic of milk yield and fertility traits in Holstein-Friesian cattle on large scale Kenyan farms. J. Anim. Sci., 79: 14421450 .

Pryce, J.E.; M.P. Coffey and S.Brotherstone, 2000. The genetic relationship between calving intervals, body condition score and linear type management traits in registered Holstein. J. Dairy Sci., 83:2664-2671.

SAS, 2004. SAS Statistics. Guide Release Edition.SAS. Inst., Inc., Cary, NC.

Short,T.H. and T.J. Lawlor, 1992. Genetic parameters of conformation traits, milk yield and herdlife in Holsteins. J. Diary Sci., 75:1987-1998.

Royal, M.; G.E. Mann and A.P.F. Flint,2000. Strategies for reversing the traind towards subfertility in dairy cattle. Vet. J., 160:53-60.

Tsuruta, S.; I. Misztal and T.J. Lawlor, 2005. Changing the definition of productive life in US Holsteins: effect on genetic correlations. J. Dairy Sci., 88: 1156-1165.

Van Raden, P.M. and G.R. Wiggans, 1995. Productive life evaluations: calculation, accuracy and economic value. J. Dairy Sci., 78: 631-638.

Vollema, A.R., and A.F. Groen, 1996. Genetic parameters of longevity traits of an upgrading population of dairy cattle. J. Dairy sci., 79: 2261-2267. 


\section{المعالم الوراثية و المظهرية لبعض صفات طول الحياة والعمر الإنتاجى لأبقار الهولثتين فى} مزرعة تجارية بمصر التهر والمر

سامى أبو بكر

\section{قسم الإنتاج الحيوانس، كلبة الزراعة، جامعة القاهرة، الجبيزة، جههورية مصر العربية}

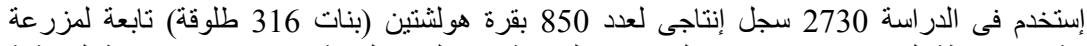

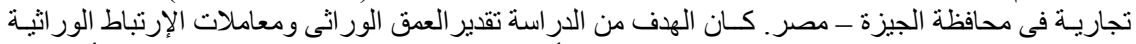

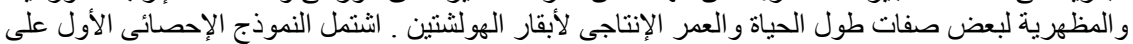

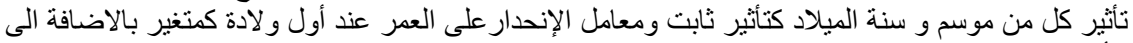

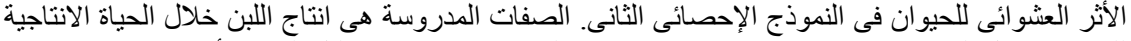

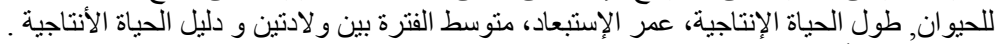

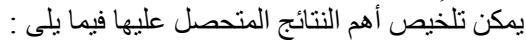

1- متوسط الصفات المدروسة هى 26936 كجم و 47.5 شهر و74.8 شهر و508.5 يوم و51.5\%؛ على الترتيب.

2- كان تقدير قيمة العمق الور اثى للصفات هو

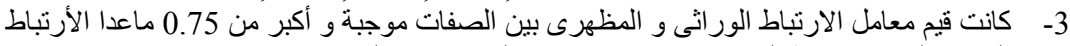

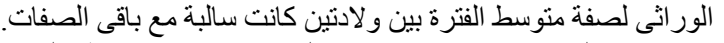

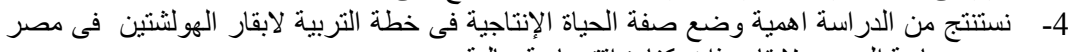
بسبب حاجة المربين لابقار ذات كفاءة إقتصادية عالية. 